\title{
COUNTRY TAX REGIME AND FIRM DEBT FINANCING
}

\author{
Grace Then, Michael Gunawan, Hendra Fong, and Adrian Teja \\ Universitas Prasetiya Mulya
}

\begin{abstract}
ABSTRAK
Rezim pajak negara ASEAN dapat dibedakan menjadi rezim pajak klasikal (Indonesia, Thailand, dan Filipina) dan rezim pajak terintegrasi (Singapura, Malaysia, dan Vietnam). Makalah ini ditujukan untuk memahami pengaruh perbedaan rezim pajak negara terhadap penggunaan hutang perusahaan. Metode penelitian yang digunakan adalah metode regresi cross section. Variabel terikat, yaitu struktur modal perusahaan diwakili oleh Debt to Equity Ratio, variabel bebas diwakili oleh variable dummy, dimana rezim pajak klasikal didefinisikan bernilai 1 dan rezim pajak terintegrasi didefinisikan bernilai 0 , dan variable kendali sebagai berikut: Net Property Plan and Equipment to Total Asset Ratio, One Year Sales Growth, Price to Book Value Ratio, dan Earnings before Interest, Taxes, Depreciation and Amortization to Total Asset Ratio. Hasil regresi menunjukkan perusahaan yang berada pada negara dengan rezim pajak klasikal menggunakan hutang yang lebih sedikit daripada perusahaan yang berada pada negara dengan rezim pajak terintegrasi. Tarif pajak pada rezim pajak klasikal lebih besar daripada tarif pajak rezim pajak terintegrasi. Tarif pajak yang lebih tinggi memberikan kesempatan penghematan pajak yang lebih besar pada perusahaan pada rezim pajak klasikal daripada perusahaan pada rezim pajak terintegrasi. Perusahaan pada rezim pajak klasikal dapat memperoleh penghematan pajak yang sama besarnya dengan perusahaan pada rezim pajak terintegrasi dengan menggunakan sumber dana hutang yang lebih kecil.
\end{abstract}

Kata kunci: Rezim Pajak Klasikal; Rezim Pajak Terintegrasi; Penghematan Pajak Dari Hutang; Pendanaan Hutang; Negara ASEAN

\begin{abstract}
The ASEAN country's tax regime can be distinguished into the classical tax regime (Indonesia, Thailand, and Philippines) and integrated tax regime (Singapore, Malaysia, and Vietnam). This paper aims to understand the effect of the different tax regimes to firm debt financing policy. We analyze the effects of different tax regimes using the cross section regression method. The dependent variable is Debt to Equity Ratio, the independent variable is proxied by a dummy variable with the classical tax regime are defined as 1 and the integrated tax regime are defined as 0 , and firms' characteristics, as a control variable: Net Property Plan and Equipment to Total Asset Ratio, One Year Sales Growth, Price to Book Value Ratio, and Earnings before Interest, Taxes, Depreciation and Amortization to Total Asset Ratio. Since the classical tax regime has higher tax rates relative to the integrated tax regime, firm operating in the classical tax regime able to experience the same debt tax saving using lower debt financing relative to firm operating in the integrated tax regime.
\end{abstract}

Keywords: ClassicalTtax Regime; Integrated Tax Regime; Debt Tax Saving; Debt Financing; ASEAN Country 


\section{INTRODUCTION}

Attaining high economic growth to alleviate poverty and increase prosperity are the government's main economics objectives. Government devise economic strategies to achieve the objectives with two main considerations. The economic strategy should be sustainable and could achieved the objectives within shortest time period possible. One strategy is to use tax policy to alter firm debt financing decision. Government allow firm to treat interest expense as part of firm's production cost. This tax policy effectively reduce firm taxable profit and lower firm tax obligation. This policy also known as debt tax saving. This policy also effectively provide incentives for firms to use more debt financing.

Economic growth supported by debt financing tends to be higher and have a longer business cycle. Economic growth supported by debt financing, specifically excess leverage as opposed to fundamental leverage, tends to create excesses and asset bubbles (Zhang et al., 2018). Asset bubbles always burst and bring severe financial crisis.

Financial crisis induced by excessive debt financing may become more prolonged and more severe. It may cut attained economic achievement back to historical conditions, or worse. The financial crisis induced by the U.S. subprime mortgage crisis in 2007-2008 crystallized the government views regarding the trustworthiness of market mechanisms in investment that supported by debt financing.

Government and central banks, while operated independently, also consider each other to reduce business cycle amplitude and prolong economic growth. Government reduce the firm's incentives to use debt financing by reducing tax subsidy. Belgium introduced Notional Interest Deduction that effectively reduce the benefit of debt tax saving and increase the benefit of equity financing (Schepens, 2016). Germany, French, Sweden, and United Kingdom introduced tax systems that differentiate tax treatment for secured debt and unsecured debt (Diemer, 2017). Central banks also put higher effort to reduce bank systemic risk by reducing the incentive to use higher leverage (Andrieş \& Nistor, 2016; Beirne \& Friedrich, 2017; Mensah \& Premaratne, 2017).

In general, countries tax policy or tax regimes can be categorized as the classical tax regime and integrated tax regime. The classical tax regime assesses firm income tax obligation and shareholder income tax obligation separately. This separate assessment results in double taxation for the shareholder. The classical tax regime entitles shareholder to firm tax obligation and dividend tax obligation. The integrated tax regime jointly assesses firm income tax obligation and shareholder income tax obligation, which results in only single taxation for the shareholder. The integrated tax regime only tax shareholder at firm level not at individual level. If the firm already paid their tax obligation, the shareholder that received dividend from the firm do not need to pay tax dividend.

PricewaterhouseCoopers (2018) shows that ASEAN (Association of South East Asian Nations) countries adopt different tax regime. ASEAN country that adopt the classical tax regime tend to have higher tax rates than country that adopt the integrated tax regime. See table 1.

Table 1. ASEAN Countries Corporate and Dividend Tax Rate

\begin{tabular}{|c|c|c|c|}
\hline Country & $\begin{array}{c}\text { Corporate } \\
\text { Tax Rate }\end{array}$ & $\begin{array}{c}\text { Dividend } \\
\text { Tax Rate }\end{array}$ & $\begin{array}{c}\text { Tax } \\
\text { Regime }\end{array}$ \\
\hline Indonesia & $25 \%$ & $15 \%$ & Classical \\
\hline
\end{tabular}




\begin{tabular}{|c|c|c|c|}
\hline Thailand & $20 \%$ & $20 \%$ & Classical \\
\hline Phillippines & $30 \%$ & $30 \%$ & Classical \\
\hline Malaysia & $25 \%$ & $0 \%$ & Integrated \\
\hline Singapore & $17 \%$ & $0 \%$ & Integrated \\
\hline Vietnam & $22 \%$ & $0 \%$ & Integrated \\
\hline Myanmar & $35 \%$ & $0 \%$ & Integrated \\
\hline $\begin{array}{c}\text { Cambodia* } \\
\text { Brunei } \\
\text { Darussalam* }\end{array}$ & $20 \%$ & $14 \%$ & Classical \\
\hline \begin{tabular}{c} 
Laos* \\
\hline
\end{tabular} & $24 \%$ & $10 \%$ & Classical \\
\hline
\end{tabular}

Source: PricewaterhouseCoopers (2018)

Note: * means not included in analysis due to firm financial data issues.

Based on different tax regime that mentioned earlier, this paper is motivated to understand the implications of different tax regime to firm debt financing decision. Current research mostly analyze the level of tax rates to capital structure decision and focuses only on one aspect of shareholder tax obligation, either at the firm level, i.e. corporate tax or shareholder level, or dividend tax. Fischer and Jensen (2019) discuss the importance of higher debt tax shield, which implicitly related to higher tax rates, to firm higher debt level. Higher debt tax shield provide firm with higher Return on Equity because their capital structure is dominated by debt financing (Armenter \& Hnatkovska, 2017; Faulkender \& Smith, 2016; Gao, 2016; Heider \& Ljungqvist, 2015; Qi, 2011; Schandlbauer, 2017; Tse \& Rodgers, 2011). Macnamara (2019) discuss the trend of declining tax rates across countries that have effect to lower firm debt level. Lin and Flannery (2013) examined shareholder personal tax treatment effect to firm debt financing decision. The classical tax regime that have dividend tax obligation and the integrated tax regime that have zero dividend tax obligation. The different tax regime have different effects on firm shareholder after tax returns and eventually on firm's payout policy, i.e., cash dividend and share repurchases (Baker et al., 2002; Bonaimé et al., 2016; Jiang et al.,2013).

Our understanding of the effect of different tax regime to firm debt financing decision is relatively limited. The tax regime analysis ensure that we simultaneously focus on both aspect of shareholder taxation, firm level, and shareholder level tax. One research that closely related to our research is Temimi, Zeitun, and Mimouni (2016). They discuss the importance of controlling countries tax regime to understand firm debt financing decision. Countries tax regime have different effect, significant or insignificant effect, to different industries.

As findings on the effect of tax rates to debt financing decision is relatively mixed, our research question: Does country tax regime (classical tax regime and integrated tax regime) have effects on firm debt financing decisions? We hypothesized that country tax regime have effects on firm's debt financing decisions. The hypothesis is tested using the cross section regression method for firm's operating in ASEAN countries. The dependent variable is Debt to Equity Ratio as a proxy for the firm's debt financing decision. The independent variable is a dummy variable with the classical tax regime are defined as 1 and the integrated tax regime are defined as 0 . According to 


\section{8 | Bina Ekonomi}

Zingales and Rajan (1995), we use control variables as follows: Net Property Plan and Equipment to Total Asset Ratio as a proxy for firm asset tangibility, One Year Sales Growth as a proxy for firm current growth rate, Price to Book Value Ratio as a proxy for firm expected future growth rate, and Earnings before Interest, Taxes, Depreciation and Amortization to Total Asset Ratio as a proxy for firm profitability.

We choose to analyze the tax regime in ASEAN countries for two reasons. First, ASEAN is an economic trade bloc with growing importance (Song, 2010). Second, ASEAN countries tax regime can be categorized into the classical tax regime and the integrated tax regime. This paper will thus contribute by provide empirical evidence on the effects of country tax regime, the classical tax regime and the integrated tax regime, on firm debt financing decision.

This research is also very timely. The trend for tax competition is getting intensified (Becker \& Fuest, 2012; Han et al., 2014; Sanz-Córdoba, 2019; Suzuki, 2014). Several countries start to adopt the integrated tax regime. For instance, Indonesia government has reduced the public firm's tax rate from 25\% in 2019 to $19 \%$ in 2020 and 2021 and $17 \%$ in 2022. Indonesia government also waive tax on dividend payment in 2021. The Indonesia government tax policy effectively match Indonesia tax rates, firm tax rates and dividend tax rates, to Singapore's firm tax rate $17 \%$ and dividend tax rate $0 \%$. The Indonesia government also effectively transtioned from the classical tax regime into the integrated tax regime.

\section{LITERATURE REVIEW AND HYPOTHESIS}

There are three drivers of economic growth: productivity growth, accumulation of capital, and accumulation of labor (Cobb \& Douglas, 2007; Solow, 2014). Among these drivers, the accumulation of capital is seen as the most important driver for developing countries. Developing countries usually already possess plenty of labor, but lack of capital. Hence, a country may enjoy higher productivity gain if additional capital is provided (Compagnucci et al., 2018).

Since capital accumulation is important in supporting developing countries productivity growth, the developing country's government provides incentives and disincentives to increase it. Government incentives and disincentives for capital accumulation are influenced by a country's growth phase (Fischer \& Jensen, 2019). In Figure 1, we can see that in the early phase of economic growth, the government has to gain higher tax revenue through higher tax rates to finance public investment, such as infrastructure. Without higher tax revenue, the government must finance their primary deficit by issuing debt.

A government needs to strike a balance between tax revenue and debt issuance. Government ensures that their primary deficit does not spiral out of control and maintain fiscal sustainability (Zubaidi et al., 2017). When a government issue debt to finance the primary deficit, the private sector is forced to pay higher interest rates and the economic growth may falter. This condition, also known as crowding out effect (Kuismanen \& Kämppi, 2010). 


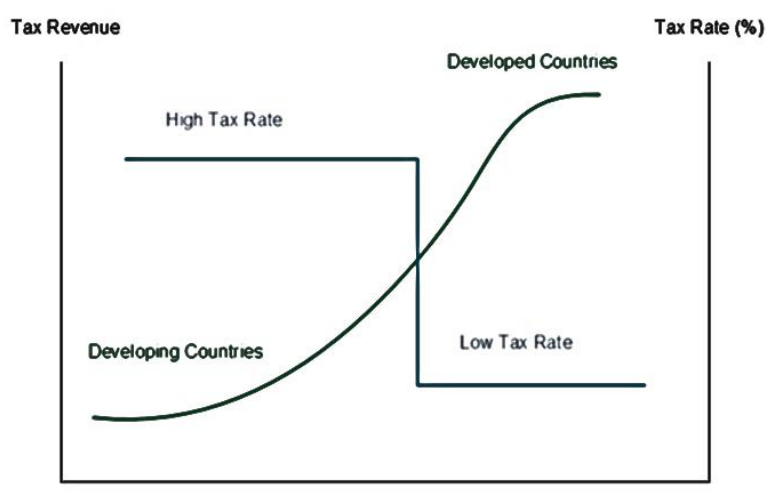

Figure 1. Economic growth life cycle phase and tax rate.

Besides debt issuance, the government also uses tax rates to stimulate economic growth. As country's public assets, such as infrastructure, become more robust and as the economy, taxation pool getting larger, government tax revenue is earned not from a higher tax rate but from a larger pool of taxable income (Besley \& Persson, 2014; Mardan \& Stimmelmayr, 2018).

The government provides the incentive for the firm to use debt financing to accelerate firm growth. It allows the firm to reduce their tax obligation. The government treats interest expense as part of production cost alongside with direct material cost, direct labor cost, and factory overhead cost. This government preferential treatment to firm debt financing decision give rise to capital structure irrelevance theorems.

The capital structure irrelevance theorem (Modigliani \& Miller, 1963; Modigliani \& Miller, 1958) does not give preferential treatment to debt financing. Debt and equity financing are treated simply as the method to distribute a firm's profit. Hence, the proportions of debt and equity do not affect firm value. The theory also suggests that the government's preferential treatment for debt financing relative to equity financing makes sources of financing relevant to the firm's value. Higher usage of debt financing results in higher government subsidies and higher shareholder value (Modigliani \& Miller, 1958). Modigliani and Miller (1963) introduced the financial distress cost to counter the benefit of debt tax saving. The improvement suggests that the optimal capital structure can be reached if the marginal benefit of debt tax saving equal to the marginal cost of financial distress cost.

The capital structure irrelevance theorem does not differentiate between firm level and shareholder level tax obligation. While in the reality, the different level tax obligation gives rise to the classical tax regime and the integrated tax regime. Both tax regimes provide preferential treatment for debt financing. Interest expense is treated similar to other production costs such as direct material, direct labor, and factory overhead. However, the classical tax regime and the integrated tax regime treat shareholder dividend tax differently. The classical tax regime encourages firms to retain their earnings and discourage dividend payment by imposing another layer of taxation on the shareholder's dividend. The classical tax regime results in double taxation of shareholder profit. The integrated tax regime encourages shareholder to distribute their firm earnings in the form of a tax free dividend. The integrated tax regime results in single taxation of the shareholder.

The different treatment to dividend tax obligation give rise to two distinct paths of debt financing decision. The first path, debt financing decision is jointly determined with shareholder tax dividend. The existence of tax dividend reduces shareholder after tax return. The shareholder 


\section{0 | Bina Ekonomi}

may demand firmness to increase their debt financing usage to leverage firm level profit. Higher firm profit may compensate shareholder dividend tax obligation. The second path, the debt financing decision is determined without consideration of shareholder tax dividend. Hence, the firm only considers the benefit of debt tax saving after considering the financial distress cost.

The first path implication is firm that operationally in the classical tax regime tend to have larger debt financing relative to firms that operating in the integrated tax regime. The second path implication is firm that operationally in the classical tax regime tend to have smaller debt financing relative to firm operating in the integrating tax regime. A firm operating in the higher tax rate country, as in the classical tax regime, may receive similar debt tax saving using less debt financing than firm operating in the lower tax rate country, as in the integrated tax regime. Based on these considerations, we formulate the following hypothesis:

$\mathrm{H}_{1}$. Tax regime have effect to firm financing decision.

Since firm debt financing is influenced by firm characteristics, it is imperative to choose which firm characteristics that may influence the firm decision to use debt financing. Firm characteristics are asset tangibility, current firm growth, future firm growth, and profitability (Zingales \& Rajan, 1995).

Creditors usually ask for collateral as another layer of protection from a debt default. The collateral should have a stable value. The consensus for assets that have stable value is an asset that has high tangibility, such as land, buildings, and machines. The high tangibility firm may obtain debt financing more easily than firm with low tangibility. Based on this consideration, asset tangibility will have a positive relationship with firm debt financing. We measure asset tangibility using Net Property, Plant, and Equipment to Total Asset Ratio.

When firm growth is higher, debt financing is a preferable source of financing relative to equity financing. Shareholders of a firm with larger firm growth may want to keep all the profit for themselves. Hence, the shareholder will be reluctant to give approval for a firm to issue new shares.

We distinguish firm growth in current growth and expected future growth. Firm with higher current growth will demand higher working capital and investment. Based on this consideration, firm current growth and expected future growth will have a positive relationship with firm debt financing. We measure firm current growth using One Year Sales Growth and firm expected future growth using Price to Book Value Ratio.

Firm profitability has a direct effect on equity accumulation. Higher profitability will speed up equity accumulation assuming no dividend payouts. Higher equity value enables the firm to have larger borrowing capacity. Hence, profitability will have a positive relationship with debt financing. We measure firm profitability using Earnings Before Interest, Taxes, Depreciation, and Amortization to Total Asset.

We present the hypothesis and firm's characteristics' effects to debt financing decision in table 2 . 
Table 2. Dependent variable, independent variable, control variable and their expected effect to firm's debt financing decision

\begin{tabular}{|c|l|c|c|c|}
\hline No & \multicolumn{1}{|c|}{ Description } & Abbreviation & $\begin{array}{c}\text { Variable } \\
\text { Definition }\end{array}$ & $\begin{array}{c}\text { Firm's debt } \\
\text { financing } \\
\text { decision }\end{array}$ \\
\hline 1 & Debt financing decision & DER & $\begin{array}{c}\text { Debt to Equity } \\
\text { Ratio }\end{array}$ & \\
\hline 2 & Tax regime & dTax & $\begin{array}{c}\text { Classical tax } \\
\text { regime are } \\
\text { defined as 1, and } \\
\text { integrated tax } \\
\text { regime are } \\
\text { defined as } 0 .\end{array}$ & $+/-$ \\
\hline 3 & Asset tangibility & NetPPE & $\begin{array}{c}\text { Net Property, } \\
\text { Plant, and } \\
\text { Equipment to } \\
\text { Total Asset Ratio }\end{array}$ & + \\
\hline 4 & Firm's current growth & 1YSales & $\begin{array}{c}\text { One year sales } \\
\text { growth relative to } \\
\text { prior year sales. }\end{array}$ & + \\
\hline 5 & Firm's expected future growth & PBV & $\begin{array}{c}\text { Price to Book } \\
\text { Value Ratio }\end{array}$ & + \\
\hline 6 & Firm's profitability & EBITDA & $\begin{array}{c}\text { Earnings Before } \\
\text { Interest, Taxes, } \\
\text { Depreciation, and } \\
\text { Amortization to } \\
\text { Total Asset Ratio }\end{array}$ & + \\
\hline
\end{tabular}

\section{DATA AND RESEARCH METHODOLOGY}

\subsection{Data}

To test our hypotheses, we choose several ASEAN countries that can be categorized as country with the classical tax regime and country with the integrated tax regime. The classical tax regime country are Indonesia, Thailand, and Philippines. The integrated tax regime are Singapore, Malaysia, and Vietnam. We do not use the other four ASEAN countries such as Myanmar, Cambodia, Brunei Darussalam, and Laos due to lack of public company data consideration.

The firm's data is obtained from S\&P Capital IQ. The criteria for firm screening in S\&P Capital IQ are as follows: the data from year end of 2019, the firm located in ASEAN country, the firm operating in all industry except financial services industry, and all financial data have to be higher than zero. The screening results in 646 firm observation from Indonesia, Thailand, Philippines, Singapore, Malaysia, and Vietnam.

\subsection{Research Methodology}

The effect of the country tax regime on firm's debt financing decision were tested using cross section regression method. We performed three cross section regressions using Stata statistical software. First, we test the effect of the different country tax regime on the use of debt financing. We define different country tax regimes using a dummy variable: classical tax regime 


\section{2 | Bina Ekonomi}

are defined as 1 and integrated tax regime are defined as 0. Firm's debt financing is proxied by the Debt to Equity Ratio. Second, we test the effect of firm's financial characteristics to the debt financing decision. Third, we simultaneously test country tax regime and firm's characteristics' effect to the debt financing decision. In doing so, we were able to identify the effect from tax regime and the firm's financial characteristics to firm's debt financing decision partially and simultaneously.

The proposed cross section regression model are as follows:

$$
\begin{aligned}
& D E R_{i j}=\alpha_{i j}+\beta_{1} \operatorname{dTax}_{i j}+\varepsilon_{i j} \\
& D E R_{i j}=\alpha_{i j}+\beta_{1} \operatorname{NetPPE}_{i j}+\beta_{2} \text { IYSales }_{i j}+\beta_{3} P B V_{i j}+\beta_{4} \text { EBITD }_{i j}+\varepsilon_{i j} \\
& D_{E R_{i j}}=\alpha_{i j}+\beta_{1} \text { dTax }_{i j}+\beta_{2} \text { NetPPE }_{i j}+\beta_{3} \text { YYSales }_{i j}+\beta_{4} P B V_{i j}+\beta_{5} \text { EBITDA }_{i j}+\varepsilon_{i j}
\end{aligned}
$$

Where

$$
\begin{aligned}
& \text { DER } \quad=\text { Debt to Equity ratio } \\
& \text { dTax }=\text { dummy tax regime, classical tax regime are defined as } 1 \text {, integrated tax regime }
\end{aligned}
$$

After we obtain the regression results, we perform and report the standard statistical test results for the cross section regression: heteroskedastic test using Breusch-Pagan/CookWeisberg test using Stata syntax hettest, and multicollinearity test using Value Inflation Factor (VIF) using Stata syntax .vif.

\section{RESULTS AND DISCUSSION}

\subsection{Results}

Table 3 shows the descriptive statistics of our data sample. The data sample is relatively diverse, from no debt firms with Debt to Equity Ratio equals or below $10 \%$ to firms in financial distress with Debt to Equity Ratio more than 100\%. Firms operating in countries that adopt the classical tax regime use higher debt financing than those in countries that adopt the integrated tax regime. The firms in classical tax regimes have average Debt to Equity Ratio 0.70 while those in integrated tax regime have average Debt to Equity Ratio 0.68. However, Debt to Equity Ratio standard deviation in the integrated tax regime is almost twice larger than the classical tax regime. Hence, we need results from regression analysis to gain clearer insight on Debt to Equity Ratio in the classical tax regime and the integrated tax regime. 
The firms operated in the classical tax regime have higher tangibility as shown by higher, Net Property, Plant, and Equipment to Total Asset Ratio (NetPPE), than firms operated in the integrated tax regime. The firms in the classical tax regime have average NetPPE 0,36 while the integrated tax regime have average NetPPE 0,33.

Investors have higher firm's future growth expectation in the classical tax regime relative to the integrated tax regime. Firms in the classical tax regime have average Price to Book Value Ratio 2.39 while the integrated tax regime have average Price to Book Value Ratio 1.85. The future growth expectations seems not related to firm's current growth as measured by One Year Sales Growth (1YSales) and relatively the same Earnings Before Interest, Tax, Depreciation, and Amortization to Total Asset Ratio (EBITDA). The firms in the classical tax regime have 1YSales average 0.34 that is lower than the integrated tax regime 1YSales average 1.66. EBITDA for the classical tax regime and the integrated tax regime have average more or less 0.11 .

Table 3. Descriptive Statistics

\begin{tabular}{|c|c|c|c|c|c|}
\hline Description & $\mathbf{N}$ & Mean & $\begin{array}{c}\text { Std. } \\
\text { Deviation }\end{array}$ & Min & Max \\
\hline DER & 646 & 0,69 & 1,36 & 0,00 & 26,58 \\
\hline NetPPE & 646 & 0,35 & 0,24 & 0,00 & 0,97 \\
\hline 1YSales & 646 & 0,99 & 15,91 & 0,00 & 402,31 \\
\hline PBV & 646 & 2,12 & 3,45 & 0,10 & 46,50 \\
\hline EBITDA & 646 & 0,11 & 0,09 & 0,00 & 0,74 \\
\hline \multicolumn{6}{|l|}{ Classical Tax Regime } \\
\hline DER & 327 & 0,70 & 0,93 & 0,00 & 7,65 \\
\hline NetPPE & 327 & 0,36 & 0,26 & 0,00 & 0,93 \\
\hline 1YSales & 327 & 0,34 & 1,97 & 0,00 & 35,06 \\
\hline PBV & 327 & 2,39 & 4,14 & 0,10 & 46,50 \\
\hline EBITDA & 327 & 0,11 & 0,08 & 0,00 & 0,74 \\
\hline \multicolumn{6}{|c|}{ Integrated Tax Regime } \\
\hline DER & 319 & 0,68 & 1,70 & 0,00 & 26,35 \\
\hline NetPPE & 319 & 0,33 & 0,23 & 0,00 & 0,97 \\
\hline 1YSales & 319 & 1,66 & 22,58 & 0,00 & 402,31 \\
\hline PBV & 319 & 1,85 & 2,52 & 0,12 & 24,30 \\
\hline EBITDA & 319 & 0,11 & 0,09 & 0,00 & 0,57 \\
\hline
\end{tabular}

Table 4 lists the cross section regression results for the effect of country tax regime on firm's debt financing decision. The regression results shows that firms operating in classical tax regime have lower debt financing relative to those in integrated tax regimes. The dummy variable for tax regime (dTax) in model 1 and model 3 have value -0.2715 and -0.2773 respectively and 


\section{4 | Bina Ekonomi}

both statistically significant at alpha 5\%. These findings statistically support our hypothesis that tax regime have effects to firm's debt financing decisions.

There are only one control variable that statistically significant. Firm's asset tangibility have positive relations with the debt financing level. The coefficient of NetPPE in model 2 and model 3 are 0.0626 and 0.0686 with alpha $10 \%$ and 5\% respectively. The other control variable, such as current firm's growth as proxied by One Year Sales Growth (1YSales), future firm's growth as proxied by Price to Book Value Ratio (PBV), and profitability as proxied by Earnings Before Interest, Tax, Depreciation, and Amortization to Total Asset Ratio (EBITDA), are not statistically significant at alpha $10 \%$.

Our regression model's explanation power of as measured by $\mathrm{R}^{2}$ is very small. Regression 1 has an $\mathrm{R}^{2}$ equal to $0.73 \%$, regression 2 has an $\mathrm{R}^{2}$ equal to $1.06 \%$, and regression 3 has an $\mathrm{R}^{2}$ equal to $1.81 \%$. This finding also implies that the tax regime, i.e. dummy variable, and control variable, i.e., firm's characteristics, have independent effects on firm's debt financing decision.

Table 4. Regression results

\begin{tabular}{|l|c|c|c|}
\hline \multicolumn{1}{|c|}{ Descriptive Statistics } & $\mathbf{1}$ & $\mathbf{2}$ & $\mathbf{3}$ \\
\hline $\mathrm{dTax}$ & $-0,2715^{* *}$ & & $-0,2773^{* *}$ \\
\hline NetPPE & & $0.0626^{*}$ & $0.0686^{* *}$ \\
\hline 1YSales & & 0,0597 & 0.0606 \\
\hline PBV & & $-0,0717$ & $-0,5787$ \\
\hline EBITDA & & $-0,0116$ & -0.0172 \\
\hline Constant & $0.223^{* * *}$ & $2,6322^{* * *}$ & $2,7368^{* * * *}$ \\
\hline $\mathrm{R}^{2}$ & 0.0073 & 0.0106 & 0.0181 \\
\hline $\mathrm{n}$ & 646 & 646 & 646 \\
\hline
\end{tabular}

Note: $* * *, * *, *$ means significant at alpha $1 \%, 5 \%$, and $10 \%$ respectively.

We report heteroskedastic test in table 5 and multicollinearity test in table 6 . The heteroskedastic test have $\chi^{2}$ larger than 0.05 or the data is homoskedastic. Our test for multicollinearity using Value Inflation Factor (VIF) measures shows low multicollinearity among variables with average VIF 1.13.

Table 5. Breusch-Pagan test for heteroskedasticity

\begin{tabular}{|c|c|c|}
\hline Description & $\chi^{2}$ & Prob $>\chi^{2}$ \\
\hline Heteroskedastic & 0,24 & 0,6213 \\
\hline
\end{tabular}

Table 6. Test for multicollinearity

\begin{tabular}{|l|c|c|}
\hline \multicolumn{1}{|c|}{ Variable } & VIF & 1/VIF \\
\hline dTax & 1,02 & 0,9832 \\
\hline NetPPE & 1,07 & 0,9302 \\
\hline 1YSales & 1,01 & 0,9867 \\
\hline PBV & 1,24 & 0,8057 \\
\hline EBITDA & 1,29 & 0,7748 \\
\hline Mean VIF & 1,13 & \\
\hline
\end{tabular}

\subsection{Discussion}

The classical tax regime impose two layer tax obligation: firm level and shareholder level tax obligation. The descriptive statistics shows that firm's average Earnings Before Interest, Tax, Depreciation, and Amortization to Total Asset (EBITDA) in the classical tax regime and the integrated tax regime are relatively the same. The classical tax regime EBITDA have average 0.11 
and the integrated tax regime have average 0.11 . The shareholder level tax obligation will effectively reduce shareholder after tax return. However, the cross section regression results shows that firm in the classical tax regime have lower average Debt to Equity Ratio relative to firm in the integrated tax regime.

The results suggest that firm only consider tax obligation at the firm level obligation since the shareholder can defer dividend tax obligation payment by reduce dividend payout ratio that effectively increase firm's retained earnings. Firm also have option to distribute profit by other mean, i.e. share repurchase, than cash dividend. The tax rates for cash dividend is larger than tax rate for capital gain. Share repurchase is more tax efficient than cash dividend. Hence, tax obligation at the firm level is more relevant than tax obligation at the shareholder level. The classical tax regime have relatively higher tax rates than the integrated tax regime. Higher tax rates enable firm in the classical tax regime to gain equal debt tax saving to the integrated tax regime using lower debt financing.

Our regression model have very low $\mathrm{R}^{2}$. This results suggest that eventhough tax regime is important, countries' different institutional setting, such as economic growth phase, have more significant effect to explain firm's debt financing decision. The sample shows that the classical tax regime and the integrated tax regime countries consist of developed and developing countries. The classical tax regime consist of Malaysia as developed country and Indonesia and Philippines as developing country. The integrated tax regime consist of Singapore as developed country and Vietnam and Myanmar as developing country. Our research only consider countries' tax regime and not yet consider countries' growth phase. Hence, we suggest that future research can be performed by analyzing the simultaneous effect of countries' different growth phase to firm's debt financing decision in the context of different tax regime.

\section{CONCLUSION}

Government may impose two layer of taxation at firm and shareholder level, i.e. the classical tax regime, or may impose only one layer of taxation at firm level, i.e. the integrated tax regime. Tax policy is a powerful instrument for government to alter firm's debt financing decision. However, as economic risk from debt financing start increasing, government reduce the incentive for firm to use debt financing. Tax competition also have role in reducing firm's tax rate.

The existence of two layer taxation may alter the firm's debt financing decision. However, our cross section regression results find that firm in the classical tax regime have lower debt level than firm in the integrated tax regime. The results suggest firm in the classical tax regime that have higher tax rates have lower debt level than firm in the integrated tax regime. Dividend payment is not mandatory. Firm may reduce their dividend payout ratio. Firm also have alternative to distribute profit beside cash dividend. Firm may distribute their profit through share repurchase. The tax rate for dividend tax rates is larger than the tax rate for capital gain. Hence, share repurchase is a tax efficient method to distribute firm's profit.

Eventhough country tax regime statistically have effect to firm's debt financing decision, our model $\mathrm{R}^{2}$ is very small less than $2 \%$. Countries' different institutional setting, such as different economic growth phase, is more important to explain the firm's debt financing decision. More research is needed to understand the simultaneous effect of countries' tax regime and their different growth phase to firm's debt financing decision. 


\section{REFERENCES}

Andrieș, A. M., \& Nistor, S. (2016). Systemic risk, corporate governance and regulation of banks across emerging countries. Economics Letters, 144, 59-63. https://doi.org/https://doi.org/10.1016/j.econlet.2016.04.031

Armenter, R., \& Hnatkovska, V. (2017). Taxes and capital structure: Understanding firms' savings. Journal of Monetary Economics, 87, 13-33. https://doi.org/10.1016/j.jmoneco.2017.03.001

Baker, M., Wurgler, J., Acharya, V., Aggarwal, R., Baker, K., Cohen, R., D 'avolio, G., Figlewski, S., Gabaix, X., Gompers, P., Heider, F., Jenter, D., John, K., Kaplan, S., Long, J., Martinez-Jerez, A., Mayer, C., Mueller, H., Ofek, E., ... Warner, J. (2002). A Catering Theory of Dividends * A Catering Theory of Dividends. LIX(3). https://archive.nyu.edu/bitstream/2451/26448/2/02-12.pdf

Becker, J., \& Fuest, C. (2012). Transfer pricing policy and the intensity of tax rate competition. Economics Letters, 117(1), 146-148. https://doi.org/10.1016/j.econlet.2012.04.061

Beirne, J., \& Friedrich, C. (2017). Macroprudential policies, capital flows, and the structure of the banking sector. Journal of International Money and Finance, 75, 47-68. https://doi.org/https://doi.org/10.1016/j.jimonfin.2017.04.004

Besley, T., \& Persson, T. (2014). Why do developing countries tax so little? Journal of Economic Perspectives, 28(4), 99-120. https://doi.org/10.1257/jep.28.4.99

Bonaimé, A. A., Hankins, K. W., \& Jordan, B. D. (2016). The cost of financial flexibility: Evidence from share repurchases. Journal of Corporate Finance, 38, 345-362. https://doi.org/10.1016/j.jcorpfin.2016.02.002

Cobb, Charles W . Cobb ; Douglas, P. H. . (2007). A Theory of Production. The American Economic Review, Vol.18, No .1, Supplement, Papers and Proceedings of the Fortieth Annual Meeting of the American Economic Association . ( Mar ., 1928), pp . 139-165 . Production, 18(1), 139165.

Compagnucci, F., Gentili, A., Valentini, E., \& Gallegati, M. (2018). Have jobs and wages stopped rising? Productivity and structural change in advanced countries. Structural Change and Economic Dynamics. https://doi.org/10.1016/j.strueco.2018.07.003

Diemer, M. (2017). Bank levy and bank risk-taking. Review of Financial Economics, 34, 10-32. https://doi.org/10.1016/j.rfe.2017.06.001

Faulkender, M., \& Smith, J. M. (2016). Taxes and leverage at multinational corporations. Journal of Financial Economics, 122(1), 1-20. https://doi.org/10.1016/j.jfineco.2016.05.011

Fischer, M., \& Jensen, B. A. (2019). The debt tax shield in general equilibrium. Journal of Banking and Finance, 100, 151-166. https://doi.org/10.1016/j.jbankfin.2018.12.014

Gao, R. (2016). An Empirical Study on the Influence of Non-Debt Tax Shield on the Choice of Corporate Debt Levels----Based On the Tax Preference Policy. International Journal of Business and Social Science, 7(1), 201-212. https://ijbssnet.com/journals/Vol_7_No_1_January_2016/21.pdf

Han, Y., Pieretti, P., \& Zou, B. (2014). Does size asymmetry exacerbate the inefficiency of tax competition? Economics Letters, 122(1), 16-18. https://doi.org/10.1016/j.econlet.2013.10.026

Heider, F., \& Ljungqvist, A. (2015). As certain as debt and taxes: Estimating the tax sensitivity of leverage from state tax changes. Journal of Financial Economics, 118(3), 684-712. https://doi.org/10.1016/j.jfineco.2015.01.004

Jiang, Z., Kim, K. A., Lie, E., \& Yang, S. (2013). Share repurchases, catering, and dividend substitution. Journal of Corporate Finance, 21(1), 36-50. 
https://doi.org/10.1016/j.jcorpfin.2013.01.004

Kuismanen, M., \& Kämppi, V. (2010). The effects of fiscal policy on economic activity in Finland. Economic Modelling, 27(5), 1315-1323. https://doi.org/10.1016/j.econmod.2010.01.010

Lin, L., \& Flannery, M. J. (2013). Do personal taxes affect capital structure? Evidence from the 2003 tax cut. Journal of Financial Economics, 109(2), 549-565. https://doi.org/10.1016/j.jfineco.2013.03.010

Macnamara, P. (2019). Taxes and financial frictions: Implications for corporate capital structure. Journal of Economic Dynamics and Control, 101, 82-100. https://doi.org/10.1016/j.jedc.2019.02.004

Mardan, M., \& Stimmelmayr, M. (2018). Tax Competition in Developed , Emerging and Developing Regions - Same Same but Different?. CESifo Working Paper no. 7090, 1-40

Mensah, J. O., \& Premaratne, G. (2017). Systemic interconnectedness among Asian Banks. Japan and the World Economy, 41, 17-33. https://doi.org/10.1016/j.japwor.2016.12.004

Miller, F., \& Miller, M. H. . (1963). American Economic Association Corporate Income Taxes and the Cost of Capital : A Correction Author ( s): Franco Modigliani and Merton H. Miller Source : The American Economic Review, Vol . 53 , No. 3 (Jun ., 1963 ), pp . 433-443 Published by: Americ. The American Economic Review, 53(3), 433-443. http://lib.cufe.edu.cn/upload_files/other/4_20140512101629_02.pdf

Modigliani, F., \& Miller, M. H. (1958). The Cost of Capital, Coorporate Finance and the theory of investment. The American Econoic Review, 568(3), 261-297.

PricewaterhouseCoopers. (2018). Worldwide tax summaries. Corporate taxes 2018/19. 2839. http://taxsummaries.pwc.com/vwLUFiles/Archive_WWTS_Corporate_Taxes_201819_PDF/\$file/PwC WWTS - Corporate Taxes 2018-19.pdf

Qi, H. (2011). Value and capacity of tax shields: An analysis of the slicing approach. Journal of Banking and Finance, 35(1), 166-173. https://doi.org/10.1016/j.jbankfin.2010.07.030

Sanz-Córdoba, P. (2019). The role of infrastructure investment and factor productivity in international tax competition. Economic Modelling. https://doi.org/10.1016/j.econmod.2019.05.003

Schandlbauer, A. (2017). How do financial institutions react to a tax increase? Journal of Financial Intermediation, 30, 86-106. https://doi.org/10.1016/j.jfi.2016.08.002

Schepens, G. (2016). Taxes and bank capital structure. Journal of Financial Economics, 120(3), 585-600. https://doi.org/https://doi.org/10.1016/j.jfineco.2016.01.015

Solow. (2014). A contribution to the theory of economic growth: Old and New. Journal of Economics and International Finance, 6(3), 47-61. https://doi.org/10.5897/jeif2013.0518

Suzuki, M. (2014). Corporate effective tax rates in Asian countries. Japan and the World Economy, 29, 1-17. https://doi.org/10.1016/j.japwor.2013.11.001

Temimi, A., Zeitun, R., \& Mimouni, K. (2016). How does the tax status of a country impact capital structure? Evidence from the GCC region. Journal of Multinational Financial Management, 3738, 71-89. https://doi.org/10.1016/j.mulfin.2016.08.002

Tse, C. B., \& Rodgers, T. (2011). Can corporate tax shields explain the long-term borrowing behaviour of Chinese listed firms? International Review of Financial Analysis, 20(2), 103-112. https://doi.org/10.1016/j.irfa.2011.02.011

Zhang, X., He, Z., Zhu, J., \& Li, J. (2018). Quantity of finance and financial crisis: A non-monotonic investigation 败. North American Journal of Economics and Finance, 44(December 2017), 129- 
38 | Bina Ekonomi

139. https://doi.org/10.1016/j.najef.2017.12.001

Zingales, L., \& Rajan, R. G. (1995). What Do We Know about Capital Structure? Some Evidence from International Data. The Journal of Finance, 50(5), 1421-1460. https://doi.org/10.1111/j.1540-6261.1995.tb05184.x

Zubaidi, A., Soon, S., \& Lau, E. (2017). Fiscal sustainability in an emerging market economy : When does public debt turn bad? Journal of Policy Modeling, 39(1), 99-113. https://doi.org/10.1016/j.jpolmod.2016.11.002 